\begin{tabular}{l|l} 
Jurnal Eksplorasi Akuntansi & $\begin{array}{l}\text { ISSN : 2656-3649 (Online) } \\
\text { holtp://jea.ppj.unp.ac.id/index.php/jea/issue/view/30 }\end{array}$
\end{tabular}

\title{
Pengaruh Financial Distress, Leverage, Dan Profitabilitas Terhadap Konservatisme Akuntansi
}

\author{
Iddha Wahyu Dwi Putra', Vita Fitria Sari² \\ ${ }^{1}$ Alumni Jurusan Akuntansi Fakultas Ekonomi Universitas Negeri Padang \\ 2,3 Jurusan Akuntansi Fakultas Ekonomi Universitas Negeri Padang \\ *Korespondensi: wahyudp55@gmail.com
}

\begin{abstract}
This study aims to prove empirically the effect of financial distress, leverage and profitability on accounting conservatism. The sample selection in this study used a purposive sampling method with various criteria according to the objectives of the study. The total samples used as research objects in this study were 60 manufacturing companies. The data analysis used in this research is descriptive statistics using logistic regression analysis techniques. The results of this study can prove that financial distress has no effect on accounting conservatism. A regression coefficient of -0.171 of one unit will reduce accounting conservatism by 0.171 units. The significance value (sig) of 0.389> greater than 0.05, it can be concluded that the hypothesis $H_{1}$ is rejected. In addition, this study can also prove empirically that leverage has a positive effect on accounting conservatism with a sig value of $0.026<0.05$. Then it can be concluded that the $\mathrm{H}_{2}$ Hypothesis is Accepted. Meanwhile, the profitability variable has an effect on accounting conservatism with a significance value (sig) of 0.022 less than 0.05. So it can be concluded that the $\mathrm{H}_{3}$ Hypothesis is Accepted. Suggestions for further research are expected to increase the number of research samples and also the year of observation. Can also use other variables that are used to measure accounting conservatism. While the overall contribution in this study was $5.7 \%$ while $94.3 \%$ was influenced by other factors or other variables not included in this study.
\end{abstract}

Keywords: Financial Distress, Leverage, Probitability, Conservatism Accounting, Company Manufacture.

How to cite (APA $6^{\text {th }}$ style):

Putra, I. W. D \& Sari, V. F. (2020). Pengaruh Financial Distress, Leverage, dan Profitabilitas terhadap Konservatisme Akuntansi. Jurnal Eksplorasi Akuntansi, 2(4), Seri B, 35003516.

\section{PENDAHULUAN}

Globalisasi memicu persaingan antara pelaku-pelaku bisnis dan perkembangan usaha yang semakin pesat dari waktu ke waktu. Berbagai cara dilakukan perusahaan guna untuk mempertahankan diri. Salah satu cermin baiknya suatu manajemen perusahaan dalam mengelolah dan mengoptimalkan sumber daya perusahaan dapat di gambarkan dalam laporan keuangan. 
Laporan keuangan adalah catatan informasi keuangan suatu perusahaan pada suatu periode akuntansi yang dapat digunakan untuk menggambarkan kinerja perusahaan tersebut. Laporan keuangan yang dibuat dan disajikan oleh perusahaan merupakan laporan dari hasil perusahaan dalam setiap akhir periodenya, yang dibuat sebagai informasi yang menunjukan bagaimana kondisi perusahaan kepada pihak internal maupun eksternal. Laporan keuangan dapat dijadikan bahan pertimbangan dan evaluasi dalam pengambilan keputusan. Sebagai laporan yang menyajikan informasi yang relevan, laporan keuangan memiliki tujuan agar memberikan informasi yang bermanfaat bagi pemakainya. Namun dalam mencapai tujuan tersebut, manajemen seringkali di hadapkan pada ketidakpastian dari suatu kegiatan usahan perusahaan.

Menurut Soewardjono (2010), konservatisme adalah sikap dalam menghadapi ketidakpastian untuk mengambil tindakan atau keputusan atas kemungkinan hasil yang terjelek dari ketidakpastian tersebut. Implikasi konsep ini terhadap prinsip akuntansi adalah akuntansi mengakui biaya atau rugi yang kemungkinan akan terjadi, tetapi tidak segera mengakui pendapatan atau laba yang akan datang walaupun kemungkinanya besar akan terjadi.

Sedangkan Definisi resmi dari konservatisme terdapat dalam Glosarium Pernyataan Konsep No.2 FASB (Financial Accounting Statement Board) yang mengartikan konservatisme sebagai reaksi yang hati-hati (prudent reaction) dalam menghadapi ketidakpastian yang melekat pada perusahaan untuk mencoba memastikan bahwa ketidakpastian dan risiko dalam lingkungan bisnis yang sudah cukup dipertimbangkan. Jadi, dari defenisi di atas dapat disimpulkan bahwa Konservatisme akuntasi adalah suatu Variabilitas yang dapat dipilih manajemen dalam penyusunan laporan keuangan dengan tidak terlalu terburu-buru mengakui dan mengukur aktiva serta segera mengakui kerugian dan hutang yang mungkin terjadi untuk menghadapi ketidakpastian dan risiko dalam lingkup bisnis.Konservatisme sangat dibutuhkan agar dalam pengukuran dan pengakuan aktiva serta laba dapat dilakukan dengan penuh kehati-hatian.

Penerapan prinsip ini secara tidak langsung dapat mempengaruhi hasil dari laporan keuangan karna penerapan konservatisme dalam penyusunana laporan keuangan mengakibatkan pilihan metode akuntansi ditujukan pada metode yang melaporkan laba atau aktiva yang lebih rendah serta melaporkan hutang lebih tinggi. Namun menurut Alfian (2013), penggunaan prinsip konsertatisme akuntansi masih kontroversial, karena menganggap laporan keuangan menjadi tidak berkualitas dan cenderung tidak menyajikan laporan keuangan sesuai dengan keadaan yang sebenarnya, dampaknya laba yang di hasilkan menjadi understatement.

Jika dilihat dari prespektif teori keagenan dimana terdapat pemisahan antara pihak agen atau pemilik dan prinsipal atau manajemen, maka pihak manajemen dengan motivasi tertentu misalnya untuk mendapatkan bonus, cenderung ingin melaporkan angka laba yang tinggi sedangkan manajemen menginginkan informasi laba yang berkualitas. Hal tersebut berpotensi menimbulkan konflik. Untuk mencegah hal tersebut terjadi maka konservatisme akuntansi dapat diterapkan dalam penyusunan laporan keuangan. Penelitian Suprihastini dan puspariani (2007) menerangkan melalui Ni Wayan Noviantaridalam Teori Akuntansi Positif menejemen cenderung mengurangi tingkat konservatisme apabila perusahaan mengalami kesulitan keuangan atau Financial Distress. Financial Distres ini terjadi saat perusahaa gagal atau tidak mampu lagi memenuhi kewajiban kepada debitur karena kekurangan atau ketidakcukupan dana untuk menjalankan atau melanjutkan usaha lagi.

Sedangkan Penelitian Ni Wayan \& Ni Made Dwi Ratna (2015) Menjelaskan bahwa Financial Distress berpengaruh negatif terhadap konservatisme akuntansi pada perusahaan manufaktur yang terdaftar di BEI. Dengan tingginya tingkat Financial distress membuat manejer kemungkinan akan menghadapi tekanan pelanggaran kontrak. Ancaman tersebut dapat 
mendorong manejer menurunkan tingkat konservatisme dalam menyajikan laporan keuangan. Penelitian ini didukung oleh KD Sri Lestari \& Ketut Suryawan (2014), Ningsih (2013), Nugroho (2012) yang menyatakan Financial Distress berpengaruh signifikan negatif terhadap konservatisme akuntansi. Namun berbeda dengan penelitian Hesty (2008) yang menerangkan bahwa Tingkat kesulitan keuangan perusahaan tidak berpengaruh negatif signifikan terhadap kebijakan konservatisme akuntansi yang di buat oleh manejer perusahaan.

Selain financial distress, menurut beberapa penelitian terdahulu, rasio Leverage dapat juga mempengaruhi manajemen untuk melakukan praktek konservatisme akuntansi. Leverage merupakan rasio perbandingan yang menunjukkan seberapa besar porsi hutang atau modal membiayai aset perusahaan. Berdasarkan teori agensi, terdapat hubungan keagenan antara manejer dan kreditur, dimana manejer yang ingin mendapatkan dana atau kredit maka akan cendrung lebih memperhatikan rasio leveragenya. Hasil penelitian Sri lestari\& Ketut suryawan (2014) menjelaskan Leverage memiliki pengaruh positif dan signifikan terhadap konservatisme akuntansi. Kreditur akan cendrung menuntut manajemen untuk menerapkan akuntansi yang konservatif dalam menyusun laporan keuangan. Penelitian ini sejalan dengan Alhayati ( 2013) yang juga menerangkan bahwa Leverage berpengaruh signifikan positif terhadap konservatisme akuntansi. Namun berbeda dengan penelitian Dini ( 2013) dan Ni Wayan (2015) yang menerangkan bahwa Leverage berpengaruh negatif terhadap konservatisme akuntansi.

Selain kedua faktor di atas, efektivitas dan efisiensi manajemen bisa dilihat dari laba yang dihasilkan terhadap penjualan dan investasi perusahaan yang dilihat dari unsur unsur laporan keuangan atau disebut juga rasio profitabilitas. Semakin tinggi nilai rasio maka kondisi perusahaan semakin baik. Nilai yang tinggi melambangkan tingkat laba dan efisiensi perusahaan tinggi yang bisa dilihat dari tingkat pendapatan dan arus kas. Rasio-rasio profitabilitas memaparkan informasi yang pentingkan daripada rasio periode sebelumnya dan rasio pencapaian pesaing. Faktor Profitabilitas ini juga dapat mempengaruhi penerapan konservatisme akuntansi. Semakin tinggi tingkat profitabilitas suatu perusahaan, maka akan cenderung memilih akuntansi yang konservatif. Hal ini karena konservatisme digunakan oleh manajer untuk mengatur laba agar terlihat rata dan tidak terlalu memiliki fluktuasi.

Penelitian oleh Yuliani (2013) menerangkan bahwa Profitability dan Investment Opportunity Set secara parsial berpengaruh positif terhadap konservatisme akuntansi.Sejalan dengan Penelitian yang dilakukan oleh Nila Choiriyah (2016), Radyasinta Surya Pratanda (2014) dan Shirly Limantauw (2012) yang menyatakan bahwa profitabilitas berpengaruh terhadap konservatisme akuntansi. Perusahaan dengan profitabilitas tinggi akan cenderung menggunakan akuntansi yang konservatif untuk mengatur laba agar terlihat tidak terlalu memiliki fluktuasi.

Terdapat banyak penelitian yang telah dilakukan mengenai faktor-faktor yang dapat mempengaruhi konservatisme akuntansi, seperti penelitian yang dilakukan oleh Noviantari \& Ni Made (2015) dan penelitian Dewi \& Ketut Suryawan (2014) yang meneliti pengaruh financial distress dan leverage terhadap konservatisme akuntansi namun hasil yang ditemukan cenderung inkonsisten. Perbedaan dengan penelitian sebelumnya adalah karena pada penelitian ini lebih memfokuskan pembahasan konservatisme dalam kaitannya dengan laba rugi, maka peneliti menambahkan variabel Profitabilitas kedalam penelitian ini karna tingkat Profitabilitasakan mempengaruhi keputusan perusahaan untuk menerapkan prinsip akuntansi yang konservatif.

Tujuan dari penelitian ini adalah untuk membuktikan dan memperoleh bukti empiris sejauhmana pengaruh financial distress terhadap penerapan konservatisme akuntansi, sejauhmana pengaruh leverage terhadap penerapan konservatisme akuntansi daan sejauhmana pengaruh profitabilitas terhadap penerapan konservatisme akuntansi. Maka dari itu peneliti 
tertarik untuk mengambil judul penelitian yakni: "Pengaruh Financial Distress, Leverage dan Profitabilitas terhadap Penerapan Konservatisme Akuntansi"

\section{REVIEW LITERATUR DAN HIPOTESIS}

\section{Teori Keagenan (Agency Theory)}

Teori keagenan (Agency Theory) adalah teori yang melandasi penelitian ini. Teori ini dikemukakan oleh Michael C. Jensen dan Wiliam H. Meckling (1976) hubungan agensi muncul ketika satu orang atau lebih (principal) mempekerjakan orang lain (agent) untuk memberikan suatu jasa dan kemudian mendelegasikan wewenang dalam pengambilan keputusan kepada agent yang bersangkutan. Dalam prakteknya manajer sebagai pengelola perusahaan tentunya mengetahui lebih banyak informasi kondisi internal dan keberlangsungan prospek masa depan perusahaan dibandingkan dengan investor. Sehingga sebagai pengelola, manajer memiliki kewajiban memberikan informasi kepada investor mengenai kondisi dalam perusahaan.

Menurut Anthony dan Govindarajan (2005) konsep teori agensi adalah hubungan agensi ada ketika salah satu pihak (Prinsipal) menyewa pihak lain (agen) untuk melaksanakan suatu jasa, dan dalam melaksanakan hal tersebut, Prinsipal mendelegasikan wewenang untuk pengambilan keputusan kepada agen. Pada perusahaan yang modalnya terdiri dari saham, pemegang saham bertindak sebagai Principal dan mempekerjakan CEO (Chief Executive Officer) selaku agen untuk bertindak dan menjalankan perusahaan sesuai kepentingan prinsipal. Jika prinsipal dan agen memiliki tujuan yang sama maka agen akan mendukung dan melaksanakan semua yang diperintahkan oleh prinsipal.

\section{Teori Akuntansi Positif (Positive Accounting Theory)}

Teori akuntansi positif adalah teori yang berusaha menjelaskan sebuah proses yang menggunakan pemahaman, pengetahuan dan kebijakan akuntansi yang sesuai untuk menghadapi kondisi dan keadaan tertentu dimasa datang. Menurut Watts \& Zimmerman (1986) bahwa teori ini berkembang seiring dengan kebutuhan untuk menjelaskan dan memprediksi realitas praktikpraktik akuntansi yang ada di masyarakat. Teori ini mempunyai dasar pijakan yang berbeda dengan teori akuntansi normatif yang lebih cenderung menjelaskan praktik-praktik akuntansi yang seharusnya berlaku. Validasi teori akuntansi positif dapat dinilai dari kesesuaian teori dengan fakta yang terjadi.

\section{Laporan Keuangan}

Menurut Ikatan Akuntan Indonesia dalam Pernyataan Standar Akuntansi Keuangan (PSAK) No. 1 bahwa Laporan Keuangan suatu penyajian terstruktur atas posisi keuangan dan kinerja keuangan suatu entitas. Laporan keuangan juga menunjukkan hasil pertanggungjawaban manajemen atas penggunaan sumber daya yang dipercayakan kepada mereka. Laporan keuangan pada umumnya terdiri dari Laporan posisi keuangan, Laporan laba rugi, laporan perubahan ekuitas, laporan arus kas, catatan atas laporan keuangan. Menurut Munawir (2010:5), pada umumnya laporan keuangan itu terdiri dari neraca dan perhitungan laba-rugi serta laporan perubahan ekuitas. Neraca menunjukkan atau menggambarkan jumlah aset, kewajiban dan ekuitas dari suatu perusahaan pada tanggal tertentu.

\section{Konservatisme Akuntansi}

Definisi konservatisme menurut Watts (2003) merupakan sebagai perbedaan verifialibilitas atau sesuatu yang dapat diuji kembali, yang diminta untuk pengakuan laba dibandingkan rugi. Maka 
dapat diartikan secara singkat, konservatisme akuntansi adalah tidak menngantisipasi keuntungan, tetapi mengantisipasi semua kerugian. Definisi resmi dari konservatisme akuntansi terdapat dalam Glosarium pernyataan Konsep no.2 FASB (Financial Accounting Statement Board) yang mengartikan konservatisme sebagai reaksi yang hati-hati (prudent reaction) dalam menghadapi ketidak pastian yang melekat pada perusahaan untuk mencoba memastikan bahwa ketiakpastian dan resiko dalam luingkup bisnis yang sudah dipertimbangkan.

Walaupun banyak menuai kritikan tentang kegunaan konservatisme akuntansi, para peneliti beranggapan bahwa konservatisme akuntansi yang bermanfaan apabila laba konservatif disusun menggunakan prinsip kehati-hatian sehingga mencerminkan laba minimal yang dapat diperoleh oleh perusahaan, sehingga laba tersebut tidak merupakan laba yang dibesar-besarkan serta menjadi laba yang berkualitas.

\section{Pengukuran Terhadap Konservatisme Akuntansi}

Menurut Watt (2003), terdapat tiga tipe ukuran untuk mengukur konservatisme akuntansi, yaitu: Earning/stock return relation measures. Konservatisme di ukur dengan pendekatan reaksi pasar atas informasi yang di ungkapkan perusahaan. Menurut Basu (1997) konservatisme di ukur dengan cara membentuk regresi antara return saham terhadap laba. Hal ini sesuai dengan devenisi konservatisme yang mengakui kerugian yang berpeluang akan terjadi di masa depan sehingga kabar buruk lebih cepat terefleksi dalam laba dibandingkan kabar baik.

Earning/accrual measures.

Accrual measures adalah pengukuran konservatisme akuntansi dengan menggunakan akrual, yaitu selisih antara net income sebelum depresiasi dan amortisasi dan cash flow operasional. Givoly dan Hayn (2000) menyatakan bahwa apabila akrual bernilai negatif, maka laba gilongkan konservatif yang di sebabkan oleh laba lebih kecil dari pada arus kas. Net asset measures. Net asset Measures adalah metode pengukuran konservatisme akuntansi dengan melihat apakah nilai aset disajikan secara understatement dan kewajiban yang overstatement. Salah satu model pengukuran Net asset measures oleh Breaver dan Ryan (2000) untuk menghitung net asset measures menggunakan rasio market to book value ratio (market value of commonequity/book value common equity)yang mencerminkan nilai pasar relatif terhadap nilai buku perusahaan.

\section{Financial Distress}

Pengertian financial distress menurut Darsono dan Ashari (2005) dapat diartikan sebagai ketidakmampuan perusahaan untuk membayar kewajiban keuangannya disaat jatuh tempo yang menyebabkan resiko kebangkrutan atau adanya masalah likuiditas yang parah dan tidak dapat dipecahkan oleh perusahaan. Sedangkan menurut Bringham \& Daves (2003) Financial distress adalah suatu kondisi kosulitan keuangan yang dimulai dari ketidakmampuan perusahaan dalam memenuhi kewajibannya yang sudah jatuh tempo.

\section{Pengukuran Financial Distress Model Altman}

Penelitian yang dilakukan oleh Altman (1968) merupakan penelitian awal yang mengkaji pemanfaatan analisis rasio keuangan sebagai alat untuk memprediksi kebangkrutan perusahaan. Model Altman ini dikenal dengan Z-score yaitu score yang ditentukan dari hitungan standar kali nisbah- nisbah keuangan yang menunjukkan tingkat kemungkinan kebangkrutan perusahaan. 
Machfoedz (1994) menguji manfaat rasio keuangan dalam memprediksi laba perusahaan di masa yang akan datang.

\section{Leverage}

Menurut Harjito (2011) Leverage dalam pengertian bisnis mengacu pada penggunaan aset dan sumber daya (sources offound) oleh perusahaan dimana dalam penggunaan aset atau dana tersebut perusahaan harus mengeluarkan biaya tetap atau beban tetap. Menurut Agus sartono (2012) menjelaskan bahwa Leverage adalah rasio yang menunjukkan proporsi penggunaan atas hutang untuk membiayai investasinya.

\section{Profitabilitas}

Pada umumnya, perusahaan didirikan dengan tujuan untuk mendapatkan laba dan keuntungan. Profitabilitas merupakan kemampuan perusahaan dalam menghasilkan laba dalam periode tertentu dan dapat di ukur dan dinilai. Menurut kasmir (2014) rasio profitabilitas adalah rasio yang menilai kemampuan perusahaan dalam mencari keuntungan. Rasio ini juga memberikan ukuran tingkat efektifitas manajemen suatu perusahaan.

Rasio profitabilitas menurut Fahmi (2013) merupakan rasio yang digunakan unutk menunjukkan keberhasilan perusahaan didalam menghasilkan keuntungan. Investor akan menganalisa dengan cermat kelangsungan suatu perusahaan serta kemampuannya dalam menghasilkan laba. Semakin baik rasio profitabilitas, maka menggambarkan bahwa perusahaan mempunyai kemampuan yang baik dalam memperoleh keuntungan.

\section{Laba}

Laba merupakan salah satu elemen yang menjadi perhatian bagi pemakai laporan keuangan, karena angka laba dinilai memuat informasi untuk menggambarkan kinerja perusahaan secara keseluruhan. Menurut Suwardjono (2008) menjelaskan laba merupakan imbalan atas upaya perusahaan dalam menghasilkan barang dan jasa. Ini berarti laba merupakan selisih lebih pendapatan atas biaya yang melekat pada kegiatan produksi barang dan jasa tersebut.

\section{Penelitian Terdahulu}

Noviantari, Ni Wayan dan Ni Made Dwi Ratnadi (2015) melakukan penelitian tentang Pengaruh Financial Distress, Ukuran perusahaan, dan Leverage pada konservatisme akuntansi. Penelitian ini menggunakan financial disstres, ukuran perusahaan dan leverage sebagai variabel independen dan Konservatisem Akuntansi sebagai variabel dependen. Teknis analisis data yang digunakan pada penelitian ini adalah teknis analisis regresi linier berganda. Hasil dari penelitian ini menunjukkan bahwa financial disstres berpengaruh negatif terhadap konservatisme akuntansi, ukuran perusahaan berpengaruh positif terhadap konservatisme akuntansi dan leverage berpengaruh negatif terhadap konservatisme akuntansi.

Dewi, Ni Kd Sri Lestari Dan Ketut Suryawan (2014) melakukan penelitian tentang konservatisme akuntansi, dengan meneliti faktor-faktor yang mempengaruih yaitu Struktur kepemilikan manajerial, leverage dan financial distress sebagai variabel independen. Penelitian ini dilakukan pada perusahaan manufaktur yang terdaftar di Bursa Efek Indonesia periose 20092011. Teknik analisis data pada penelitian ini adalah regresi linear berganda. Hasil yang diperoleh menunjukan bahwa struktur kepemilikan manejerial dan leverage berpengaruh signifikan positif terhadap konservatisme akuntansi, sedangkan financial distress berpengaruh signifikan negatif terhadap konservatisme akuntansi. 
Penelitian yang di lakukan oleh Setyaningsih, Hesty (2008) yang meneliti tentang Pengaruh tinggkat kesulitan keuangan perusahaan terhadap konservatisme akuntansi. Isu dalam penelitian ini adalah perbedaan prediksi teori akuntansi positif dengan teori signaling. Hasil penelitian menunjukkan dengan prediksi teori akuntansi positif, tingkat kesulitan keuangan berpengaruh negatif signifikan terhadap konservatisme akuntansi. Sedangkan dengan prediksi teori signaling menunjukkan bahwa kesulitan keuangan berpengaruh positif signifikan sebagian terhadap konservatisme akuntansi

\section{Pengembangan Hipotesis}

\section{Pengaruh Financial Distress Terhadap Konservatisme Akuntansi}

Financial Distress adalah suatu kondisi keuangan perusahaan yang bermasalah, Teori akuntansi positif menggunakan teori keagenan untuk menjelaskan dan memprediksi prilaku manajemen bahwa manejer akan cenderung mengurangi tingkat konservatisme akuntansi apabila perusahaan mengalami kesulitan keuangan (Financial distress) yang tinggi (Suprihastini dan Pusparini, 2007). Manejer sebagai agen akan berupaya mengelola perusahaan dengan sebaik mungkin, namun apabila terjadi masalah keuangan pada perusahaan maka hal tersebut membuat pemegang saham menganggap manejer tidak mampu mengelolah perusahaan dengan baik sehingga mendorong pemegang saham selaku prinsipal, melakukan pergantian manejer.

Hal inilah yang mendorong timbulnya pelanggaran kontrak oleh manejer dan membuat manejer menyajikan laporan keuangan yang tidak konservatif, sehingga semakin tinggi tingkat financial distress maka semakin tidak konservatif laporan keuangan. Berdasarkan penjelasan diatas, maka dapat ditarik hipotesis sebagai berikut.

$\mathbf{H}_{1}$ : Financial Distress berpengaruh negatif terhadap konservatisme akuntansi.

\section{Pengaruh LeverageTerhadap Konservatisme Akuntansi}

Alhayati (2013) menjelelaskan bahwa rasio leverage menggambarkan hubungan antara hutang terhadap modal maupun aset. Rasio ini melihat seberapa jauh perusahaan dibiayai oleh hutang dengan kemampuan perusahaan yang digambarkan oleh modal. Pada perusahaan yang memiliki tingkat hutang yang cukup tinggi, kreditur memiliki hak hak untuk mengawasi operasional dan akuntansi perusahaan.

Sri lestari \& Ketut suryawan (2014) dalam penelitiannya menjelaskan Leverage memiliki pengaruh positif dan signifikan terhadap konservatisme akuntansi, sejalan dengan Alhayati (2013) yang juga menerangkan bahwa Leverage berpengaruh signifikan positif terhadap konservatisme akuntansi. Namun berbeda dengan penelitian Dini ( 2013) dan Ni Wayan (2015) yang menerangkan bahwa Leverage berpengaruh negatif terhadap konservatisme akuntansi. Seperti yang di jelaskan oleh penelitian terdahulu, bahwa perusahaan dengan tingkat leverage yang tinggi cenderung menggunakan akuntansi yang konservatif. Hal ini karena semakin tinggi leverage, maka semakin besar pula kemungkinan terjadinya konflik kepentingan antara kreditur dengan manajemen yang pada akhirnya mendorong permintaan diterapkannya akuntansi yang konservatif, dan semakin tinggi ratio hutang terhadap Aset, maka kreditur dan investor menilai bahwa perusahaan tersebut memiliki resiko yang tinggi pula. Berdasarkan penjelasan diatas, maka dapat ditarik hipotesis sebagai berikut.

$\mathbf{H}_{2}$ : Leverage berpengaruh positif terhadap konservatisme akuntansi 


\section{Pengaruh Profitabilitas terhadap Konservatisme Akuntansi}

Profitabilitas ialah rasio yang bertujuan untuk dapat mengetahui kemampuan perusahaan didalam menghasilkan laba selama periode tertentu serta memberikan gambaran mengenai tingkat efektifitas manajemen didalam melaksanakan kegiatan operasinya. Efektifitas manajemen dilihat dari laba yang dihasilkan terhadap penjualan serta investasi perusahaan. Penelitian yang dilakukan oleh Yuliani (2013) menerangkan bahwa Profitability dan Investment Opportunity Set secara parsial berpengaruh positif terhadap konservatisme akuntansi.Penelitian lain yang dilakukan oleh Choiriyah dan Almilia (2016) menunjukkan bahwa profitabilitas memiliki pengaruh yang signifikan terhadap konservatisme akuntansi, semakin tinggi tingkat profitabilitas suatu perusahaan, maka manajemen akan cenderung memilih akuntansi yang konservatif. Berdasarkan penjelasan diatas, maka dapat ditarik hipotesis penelitian sebagai berikut:

$\mathbf{H}_{3}$ : Profitabilitas berpengaruh positif terhadap konservatisme akuntansi

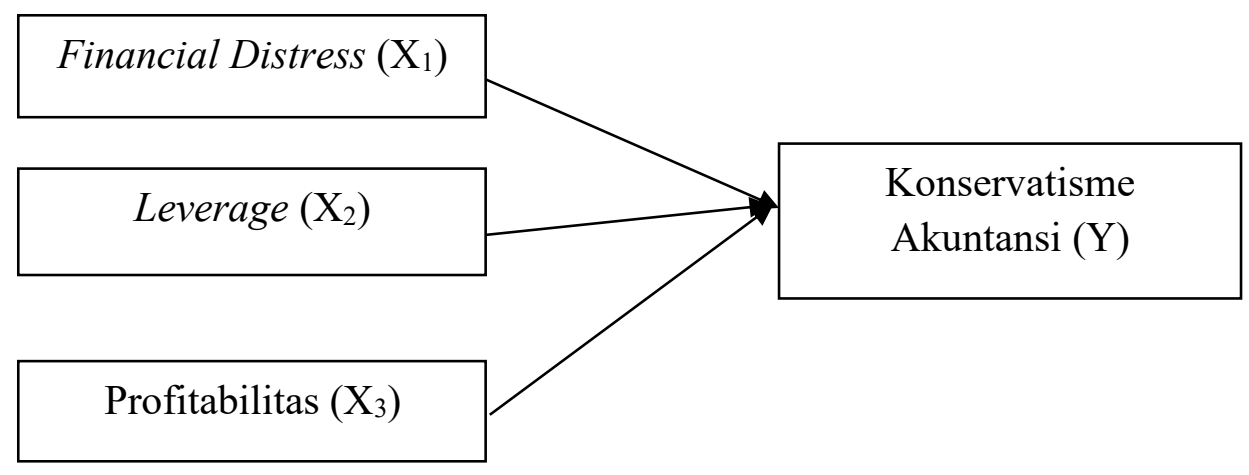

\section{Gambar 1. Kerangka Konseptual}

\section{METODE PENELITIAN}

Penelitian ini menggunakan metode penelitian kuantitatif yakni penelitian pada populasi atau sampel tertentu, adanya pengumpulan data, menggunakan instrument penelitian, analisis data bersifat kuantitatif atau statistik yang bertujuan untuk menguji hipotesis yang telah ditetapkan (Sugiyono, 2013:2).

\section{Populasi dan Sampel}

Populasi yang digunakan dalam penelitian ini adalah 26 Organisasi Perangkat Daerah (OPD) dengan berbagai tipe organisasi yang ada pada lingkungan Pemerintah Daerah Kabupaten Padang Pariaman.

\section{Sampel}

Sampel merupakan bagian dari jumlah yang dimiliki oleh populasi dan memiliki karakteristik yang sudah ditetapkan oleh peneliti (Sugiyono, 2013:80). Sampel pada penelitian ini adalah pegawai yang bekerja pada bagian keuangan Organisasi Perangkat Daerah (OPD) yakni Pejabat Penatausahaan Keuangan (PPK), Bendahara Pengeluaran, Bendahara Barang dan Staf keuangan. Pada penelitian ini penentuan sampel ditetapkan dengan teknik Purposive Sampling, yakni pengambilan sampel berdasarkan kriteria yang dipilih untuk memenuhi kebutuhan data penelitian.

Pengambilan sampel pada bagian keuangan dipilih oleh peneliti karena bagian tersebut secara aktif terlibat dalam kegiatan operasional dan teknis dari Instansi Pemerintahan. Bagian 
keuangan sangat mengetahui secara rinci kegiatan Organisasi Perangkat Daerah, sehingga ketika adanya indikasi kecurangan maupun kesalahan prosedur yang terjadi, Pegawai yang bekerja pada bagian keuangan dapat secara potensial menjadi whistleblower.

\section{Jenis, Sumber dan Teknik Pengumpulan Data}

Jenis penelitian ini tergolong penelitian kausalitas. Penelitian kausalitas bertujuan untuk mengetahui hubungan serta pengaruh variabel independen terhadap variabel dependen. Jenis data yang digunakan dalam penelitian ini adalah data dokumenter, yaitu data yang diperoleh dari dokumen sehubungan dengan objek penelitian, berupa laporan keuangan dan laporan tahunan (annual report)perusahaan manufaktur yang terdaftar di Bursa Efek Indonesia (BEI) pada tahun 2015-2019.

\section{Sumber Data}

Data yang digunakan pada penelitian ini adalah data sekunder. Data tersebut diperoleh dengancaramengunduh laporan keuangan tahunan dan laporan tahunan perusahaan manufaktur dari situs Bursa Efek Indonesia (BEI), yaitu www.idx.co.id. Selain itu, peneliti juga memperoleh data pendukung yang berkaitan dengan masalah yang diteliti melalui berbagai sumber, di antaranya buku, jurnal, karya ilmiah, artikel dan perangkat lain yang berkaitan dengan masalah penelitian.

\section{Teknik Pengumpulan Data}

Metode pengumpulan data untuk penelitian ini dengan cara melakukan pengambilan data melalui unduhan laporan keuangan tahunan dan laporan tahunan perusahaan manufaktur dari situs Bursa Efek Indonesia (BEI) dengan menggunakan metode purposive sampling sesuai dengan kriteria yang telah ditentukan didalam penelitian ini.

\section{Populasi dan Sampel}

Populasi adalah obyek/subyek yang mempunyai kuantitas dan karakteristik tertentu yang ditetapkan oleh peneliti untuk dipelajari, dan kemudian ditarik kesimpulannya. Populasi dalam penelitian ini adalah perusahaan manufaktur yang terdaftar di bursa efek indonesia tahun 20152019. Perusahaan manufaktur dipilih sebagai populasi dan sampel karena memiliki tingkat operasional yang kompleks sehingga memungkinkan untuk lebih sering menerapkan akuntansi yang konservatif.

Sampel dalam penelitian ini adalah perusahaan manufaktur yang terdaftar di Bursa Efek Indonesia tahun 2015-2019. Sampel diambil dengan metoda purposive sampling yaitu pemilihan sampel dengan kriteria tertentu. Jumlah sampel dalam penelitian ini berjumlah sebanyak 60 (Enam Puluh) Perusahaan.

\section{Metode Analisis Data}

\section{Statistik Deskriptif}

Statistik deskriptif memberikan gambaran atau deskripsi suatu objek yang diteliti melalui data sampel atau populasi sebagaimana adanya tanpa melakukan analisis dan kesimpulan secara umum. 


\section{Analisis Regresi Logistik}

Regresi logistik yaitu regresi yang digunakan sejauh mana probabilitas terjadinya variabel dependen dapat diprediksi dengan variabel independen. Teknik analisis initidak memerlukan uji normalitas data pada variable bebasnya (Ghozali, $2016: 321$ ).

\section{Pengujian Model}

Kelayakan model regresi dinilai dengan menggunakan Hosmer and Lemeshow's Goodnes of Fit Test. Jika nilai statisticHosmer and Lemeshow Goodness of fit lebih besar daripada 0,05 maka Ho tidak dapat ditolak dan berarti model mampu memprediksi nilai observasinya atau dapat dikatakan model diterima karena sesuai dengan data observasinya.

\section{Uji Koefisien Determinasi}

Koefisien determinasi digunakan untuk mengukur seberapa besar variabilitas variabel independen mampu memperjelas variabilitas variabel dependen. Koefisien determinasi pada regresi logistik dapat dilihat pada nilai Nagelkarke $R$ Square.

\section{Uji Hipotesis}

Dalam regresi logistik, baik sederhana maupun berganda, uji digunakan untuk menguji signifikansi dari pengaruh parsial. Pada regresi logistik, uji signifikansi pengaruh parsial dapat diuji dengan uji wald. Dalam uji wald, statistik yang diuji adalah statistik wald (Wald statistic). Uji hipotesis yang digunakan menggunakan T-test.

\section{Uji F-Simultan}

Menurut (Ghozali,2013:351) Untuk menguji apakah model regresi logistik yang melibatkan variabel bebas signifikan (secara simultan) lebih baik dibandingkan model sebelumnya (model sederhana) dalam hal mencocokkan data, maka bandingkan nilai Sig. untuk Step 1(Step) pada tabel Omnibus Tests of Model Coefficients yakni 0,000 terhadap tingkat signifikansi 0,05.

\section{HASIL DAN PEMBAHASAN}

\section{Gambaran Umum Objek Penelitian}

Bursa Bursa Efek Efek Jakarta pertama kali dibuka pada tanggal 14 desember 1912, dengan bantuan pemerintah kolonial Belanda, didirikan di Batavia, pusat pemerintahan kolonial Belanda yang kita kenal sekarang dengan Jakarta. Bursa Efek Jakarta dulu disebut Call-Efek. Sistem perdagangannya seperti lelang, dimana tiap efek berturut-turut diserukan pemimpin "Call", kemudian para pialang masing-masing mengajukan permintaan beli atau penawaran jual sampai ditemukan kecocokan harga, maka transaksi terjadi. Pada saat itu terdiri dari 13 perantara pedagang efek (makelar).

Pada tanggal 2 Maret 2009 Bursa Efek Indonesia meluncurkan sistim perdagangan baru yakni Jakarta Automated Trading System Next Generation(JATS Next-G), yang merupakan pengganti sistim JATS yang beroperasi sejak Mei 1995. sistem semacam JATS Next-G telah diterapkan di beberapa bursa negara asing, seperti Singapura, Hong Kong, Swiss, Kolombia dan Inggris. Demi mendukung strategi dalam melaksanakan peran sebagai fasilitator dan regulator pasar modal, BEI selalu mengembangkan diri dan siap berkompetisi dengan bursa-bursa dunia lainnya, dengan memperhatikan tingkat risiko yang terkendali, instrument perdagangan yang lengkap, sistem yang andal dan tingkat likuiditas yang tinggi. 


\section{Objek Penelitian}

Objek penelitian yang digunakan dalam penelitian adalah perusahaan manufaktur. Penelitian ini bertujuan untuk mengetahui Pengaruh Financial Distress, Leverage dan Profitabilitas Terhadap Konservatisme Akuntansi (Studi Empiris Pada Perusahaan Manufaktur yang Terdaftar di Bursa Efek Indonesia 2015-2019). Data yang digunakan dalam penelitian ini adalah data sekunder yang diperoleh dari Bursa Efek Indonesia (BEI) pada situs www.idx.co.id.

\section{Statistik Deskriptif}

Dalam penelitian ini menggunakan tiga variabel independen yakni financial distress, leverage, dan profitabilitas. Sedangkan variabel dependen dalam penelitian ini adalah konservatisme akuntansi. Gambaran dari masing-masing variabel tersebut dapat lihat pada tabel 1 sebagai berikut:

\section{Tabel 1}

Statistik Deskriptif

\begin{tabular}{lrrrrr}
\hline \multicolumn{7}{c}{ Descriptive Statistics } \\
\hline Financial Distress & \multicolumn{2}{c}{ Minimum } & Maximum & Mean & Std. Deviation \\
\hline Leverage & 300 & .00 & 2.00 & 1.2833 & .84781 \\
\hline Profitabilitas & 300 & .07 & .92 & .4021 & .18495 \\
\hline Konservatisme & 300 & -1.26 & 2.24 & .0986 & .22430 \\
\hline Valid N (listwise) & 300 & .00 & 1.00 & .4900 & .50074 \\
\hline
\end{tabular}

Sumber: Data sekunder diolah, Tahun 202

Berdasarkan hasil analisis deskriptif variabel Financial Distress memiliki rata-rata sebesar 1,2833 dengan standar deviasi 0,84781. Hal ini menunjukkan bahwa dalam data perusahaan kondisi 2 lebih banyak dibandingkan dengan kondisi 0 dan 1. Dari hasil analisis deskriptif variabel Leverage memiliki rata-rata sebesar 0,4021 dengan standar deviasi 0,18495. Nilai minimum 0,07 sedangkan nilai maksimumnya sebesar 0,92 . Nilai tersebut menunjukkan bahwa besar Leverage pada perusahaan manufaktur yang menjadi sampel pada penelitian ini berkisar antara 0,07 hingga 0,92 .

Hasil analisis deskriptif variabel Profitabilitas memiliki rata-rata sebesar 0,0986 dengan standar deviasi 0,22430 . Nilai minimum -1,26 sedangkan nilai maksimumnya sebesar 2,24. Nilai tersebut menunjukkan bahwa besar Profitabilitas pada perusahaan manufaktur yang menjadi sampel pada penelitian ini berkisar antara -1,26 hingga 2,24.Hasil analisis deskriptif variabel Konservatisme Akuntansi memiliki rata-rata sebesar 0,4900 dengan standar deviasi 0,50074.

\section{Uji Regresi Logistik}

Dalam penelitian ini, pengujian hipotesis dilakukan dengan menggunakan regresi logistik. Analisis regresi model logistik digunakan pada penelitian ini karena variabel dependen yang digunakan dalam penelitian ini bersifat dichotomous. Pengujian dilakukan dengan menggunakan dua model fit. Berikut ini hasil dari masing-masing model. 
Tabel 2

Hasil Model Fit I

\begin{tabular}{lllll}
\hline \multicolumn{4}{c}{ Iteration History ${ }^{\text {a,b,c }}$} \\
\hline \multirow{2}{*}{ Iteration } & -2 Log likelihood & & \multicolumn{2}{c}{ Coefficients } \\
\cline { 3 - 5 } Step 0 & 1 & 415.768 & Constant \\
\cline { 2 - 4 } & 2 & 415.768 & & -.040 \\
\hline
\end{tabular}

Sumber: Data sekunder diolah, Tahun 2020

Berdasarkan tabel 2 hasil uji model fit pertama dan tabel 4.3 hasil uji model fit kedua diatas, menunjukkan perbandingan antara nilai nilai -2LL blok pertama dan dengan -2LL blok kedua. Dari hasil perhitungan nilai -2LL terlihat bahwa nilai blok pertama (Block Number $=0$ ) adalah 415,768 dan nilai -2LL pada blok kedua (Block Number $=1$ ) adalah 402,626. Dengan hasil tersebut dapat disimpulkan bahwa model regresi yang kedua lebih baik, karena terdapat penurunan nilai dari blok pertama ke blok kedua.

Tabel 3

Hasil Model Fit II

\begin{tabular}{|c|c|c|c|c|c|c|}
\hline \multicolumn{7}{|c|}{ Iteration History $y^{\mathbf{a}, b, c, d}$} \\
\hline \multirow[b]{2}{*}{ Iteration } & & \multirow{2}{*}{$\begin{array}{c}-2 \log \\
\text { likelihood }\end{array}$} & \multicolumn{4}{|c|}{ Coefficients } \\
\hline & & & Constant & $\mathrm{X} 1$ & $\mathrm{X} 2$ & $\mathrm{X} 3$ \\
\hline \multirow[t]{5}{*}{ Step 1} & 1 & 403.251 & .601 & -.098 & -1.625 & 1.408 \\
\hline & 2 & 402.640 & .713 & -.161 & -1.844 & 1.976 \\
\hline & 3 & 402.626 & .726 & -.170 & -1.868 & 2.081 \\
\hline & 4 & 402.626 & .727 & -.171 & -1.869 & 2.083 \\
\hline & 5 & 402.626 & .727 & -.171 & -1.869 & 2.083 \\
\hline
\end{tabular}

Sumber: Data sekunder diolah, Tahun 2020

\section{Uji Kelayakan Model Regresi (Hosmer Test dan Lomeshow Goodness of Fit Test)}

Penilaian kelayakan model regresi dilakukan dengan menggunakan Hosmer and Lomeshow's Goodness of Fit Test. Apabila nilai signifikansi dari Hosmer and Lomeshow's Goodness of Fit Test menghasilkan nilai lebih besar daripada 0,05 maka hipotesis nol diterima. Artinya, model dapat mempresiksikan nilai observasinya dan model dapat diterima. Hasil dari uji kelayakan model regresi dapat dilihat pada tabel 4.4 sebagai berikut:

\section{Tabel 4}

Hasil Uji Hosmer dan Lomeshow's

\begin{tabular}{llcccc}
\hline \multicolumn{5}{c}{ Hosmer and Lemeshow Test } \\
\hline Step & Chi-square & Df & Sig. & \\
\hline 1 & 14.346 & & 8 & & .073 \\
\hline
\end{tabular}

Sumber: Data sekunder diolah, Tahun 2020

Dari hasil pengujian pada tabel 4 diatas, diperoleh Chi-square sebesar 14,5346 dengan nilai signifikansi sebesar 0,073 dan df 8 . Dari hasil tersebut terlihat bahwa nilai signifikan lebih besar dari 0,05 sehingga hipotesis nol diterima, yang berarti tidak ada perbedaan antara 
klasifikasi yang diprediksi dengan klasifikasi yang diamati. Sehingga dapat disimpulkan bahwa pada model regresi logistik yang digunakan telah memenuhi kecukupan data (Fit).

\section{Uji Koefisien Determinasi}

Model Summary bertujuan untuk mengetahui seberapa besar kombinasi variabel independen yaitu financial distress, leverage dan profitabilitas mampu menjelaskan variabel dependen yaitu konservatisme akuntansi. Hasil pengujian koefisien determinasi dalam penelitian ini dapat dilihat pada tabel 4.5 sebagai berikut:

Tabel 5

Hasil Uji Model Summary

\begin{tabular}{llrr}
\hline \multicolumn{4}{c}{ Model Summary } \\
\hline Step & -2 Log likelihood & Cox \& Snell R Square & Nagelkerke R Square \\
\hline 1 & $402.626^{\mathrm{a}}$ & .043 & .057 \\
\hline
\end{tabular}

Sumber: Data sekunder diolah, Tahun 2020

Berdasarkan Tabel 5 diatas, diperoleh hasil uji model -2Log Likelihood menghasilkan 402,626 dari koefisien determinasi yang dilihat dari Nagelkerke $R$ Square adalah 0,057 (5,7\%) dan nilai Cox \& Snell $R$ Square 0,043 (4,3\%). Artinya variabel independen financial distress, leverage dan profitabilitas mampu menjelaskan variasi dari variabel dependen konservatisme akuntansi sebesar 5,7\%, sedangkan sisanya dijelaskan oleh faktor-faktor lain di luar penelitian ini.

\section{Uji Parsial (T-test)}

Penelitian ini menggunakan teknik analisis data dengan menggunakan regresi logistik untuk mengetahui pengaruh secara parsial masing-masing variabel independen terhadap variabel dependen. Data uji regresi logistik secara parsial dalam penelitian ini dapat dilihat pada tabel 6 sebagai berikut:

\section{Tabel 6}

Hasil Uji Parsial (T-test)

\begin{tabular}{|c|c|c|c|c|c|c|c|}
\hline \multicolumn{8}{|c|}{ Variables in the Equation } \\
\hline & & $\mathrm{B}$ & S.E. & Wald & Df & Sig. & $\operatorname{Exp}(B)$ \\
\hline \multirow[t]{4}{*}{ Step $1^{\mathrm{a}}$} & $\mathrm{X} 1$ & -.171 & .198 & .741 & 1 & .389 & .843 \\
\hline & $\mathrm{X} 2$ & -1.869 & .841 & 4.939 & 1 & .026 & .154 \\
\hline & $\mathrm{X} 3$ & 2.083 & .909 & 5.248 & 1 & .022 & 8.031 \\
\hline & Constant & .727 & .516 & 1.984 & 1 & .159 & 2.068 \\
\hline
\end{tabular}

a. Variable(s) entered on step 1: X1, X2, X3.

Sumber: Data sekunder diolah, Tahun 2020

Dari data pada tabel 6 diatas, dapat diketahui bahwa variabel konstan model regresi logistik mempunyai koefisien positif sebesar 0,727 yang berarti jika variabel lain dianggap nol maka konservatisme akuntansimengalami kenaikan sebesar 0,727 satuan. Sementara variabel financial distress memiliki nilai statistik wald sebesar 0,741 sedangkan untuk hasil koefisien financial distress sebesar -0,171 yang berarti setiap kenaikan 1\% pada financial distress akan 
mengalami penurunan konservatisme akuntansi sebesar 0,171 satuan dengan asumsi nilai koefisien variabel lain tetap.

Variabel leverage memiliki statistik wald sebesar 4,939 sedangkan hasil koefisien leverage sebesar -1,869 yang berarti setiap kenaikan 1\% pada leverage akan mengalami penurunan konservatisme akuntansi sebesar 1,869 satuan dengan asumsi nilai koefisien variabel lain tetap. Variabel profitabilitas memiliki statistik wald sebesar 5,248 sedangkan hasil koefisien profitabilitas sebesar 2,083 yang berarti setiap kenaikan 1\% pada profitabilitas akan mengalami kenaikan pada konservatisme akuntansi sebesar 2,083 satuan dengan asumsi nilai koefisien variabel lain tetap.

\section{Uji F-Simultan}

Uji F-Simultan dilakukan untuk menguji apakah variabel-variabel financial distress, leverage \& profitabilitas terhadap konservatisme akuntansi. Uji F-Simultan dalam penelitian ini dapat dilihat pada table 7 sebagai berikut. Berdasarkan Tabel 7 di atas, menunjukkan bahwa secara simultan financial distress, leverage dan profitabilitas dapat menjelaskan mengenai konservatisme akuntansi. Hal ini dilihat dari hasil Chi-Square sebesar 13,143 dengan df sebesar 3 dan signifikansi sebesar 0,004 yang nilainya lebih kecil dari 0,05. Hal ini menunjukkan bahwa financial distress, leverage dan profitabilitas berpengaruh secara simultan terhadap konservatisme akuntansi.

Tabel 7

Hasil Uji F-Simultan

\begin{tabular}{llllll}
\hline \multicolumn{5}{c}{ Omnibus Tests of Model Coefficients } \\
\hline \multirow{5}{*}{ Step 1 } & Chi-square & df & Sig. \\
\cline { 2 - 6 } & Step & 13.143 & 3 & .004 \\
\cline { 2 - 5 } & Block & 13.143 & 3 & .004 \\
\cline { 2 - 5 } & Model & 13.143 & 3 & .004 \\
\hline
\end{tabular}

Sumber: Data sekunder diolah, Tahun 2020

\section{PEMBAHASAN}

\section{Pengaruh Financial Distress Terhadap Konservatisme Akuntansi}

Hasil dari pengujian variabel financial distress tidak mendukung hipotesis pertama yaitu terdapat pengaruh financial distress terhadap konservatisme akuntansi. Hasil ini ditunjukkan dengan koefisisen regresi sebesar -0,171 yang berarti bahwa setiap kenaikan financial distress sebesar 1 satuan akan menurunkan konservatisme akuntansi pada sebesar 0,171 satuan. Berdasarkan hasil pengujian variabel financial distress menghasilkan nilai signifikansi sebesar 0,389 dan lebih besar dari 0,05. Berdasarkan nilai signifikansi tersebut menunjukkan bahwa financial distress tidak berpengaruh terhadap konservatisme akuntansi. Sehingga dapat dinyatakan bahwa financial distress tidak berpengaruh dan tidak signifikan terhadap konservatisme akuntansi.

Hasil penelitian ini tidak konsisten dengan hasil penelitian yang dilakukan oleh Alif Lailatul Wirda (2016) yang menyatakan bahwa financial distress berpengaruh terhadap konservatisme akuntansi. Hasil ini juga tidak sesuai dengan penelitian yang dilakukan oleh Fani Risdiyani dan Kusmariyanto (2015) yang menyatakan bahwa financial distress berpengaruh terhadap konservatisme akuntansi. Financial distress berpengaruh terhadap konservatisme akuntansi. Perusahaan yang memiliki tingkat kesulitan keuangan yang tinggi akan mengarah pada kondisi keuangan perusahaan yang tidak mampu dalam menyelesaikan kondisi 
keuangannya dan akan mengarah pada kebangkrutan. Dalam hal ini perusahaan dengan tingkat kesulitan keuangan yang tinggi akan lebih berhati-hati dalam melaporkan informasi keuangannya dan akan mendorong manajer untuk lebih konservatif.

\section{Pengaruh Leverage Terhadap Konservatisme Akuntansi}

Hasil dari pengujian variabel leverage mendukung hipotesis kedua yaitu terdapat pengaruh leverage terhadap konservatisme akuntansi (Studi Empiris Pada Perusahaan Manufaktur yang Terdaftar di Bursa Efek Indonesia 2015-2019). Hasil ini ditunjukkan dengan koefisisen regresi sebesar -1,869 yang berarti bahwa setiap kenaikan leverage sebesar 1 satuan akan menurunkan konservatisme akuntansi sebesar 1,869 satuan. Berdasarkan hasil pengujian variabel laverage menghasilkan nilai signifikansi sebesar 0,026 dan lebih kecil dari 0,05. Berdasarkan nilai signifikansi tersebut menunjukkan bahwa leverage berpengaruh terhadap konservatisme akuntansi. Sehingga dapat dinyatakan bahwa leverage berpengaruh negatif dan signifikan terhadap konservatisme akuntansi (Studi Empiris Pada Perusahaan Manufaktur yang Terdaftar di Bursa Efek Indonesia 2015-2019).

Hasil penelitian ini mengindikasikan bahwa penerimaan hipotesis ini dikarenakan leverage merupakan patokan dalam konservatisme akuntansi. Menurut Alhayati (2013) menjelaskan bahwa rasio leverage menggambarkan hubungan antara hutang terhadap modal maupun aset. Rasio ini melihat seberapa jauh perusahaan dibiayai oleh hutang dengan kemampuan perusahaan yang digambarkan oleh modal. Pada perusahaan yang memiliki tingkat hutang yang cukup tinggi, kreditur memiliki hak untuk mengawasi operasional dan akuntansi perusahaan. Hak ini akan mengurangi asimetri informasi antara kreditur dengan manajer perusahaan. Manajer akan kesulitan menyembunyikan informasi dari kreditur.

Hasil penelitian ini konsisten dengan hasil penelitian yang dilakukan oleh Dini (2013) dan Ni Wayan (2015) menerangkan bahwa leverage berpengaruh negatif terhadap konservatisme akuntansi. Besarnya rasio leverage mengindikasikan kondisi perusahaan yang tidak begitu baik atau beresiko, sehingga manajer cenderung untuk meningkatkan laba agar kondisi keuangan terlihat baik oleh kreditur. Kreditur berkepentingan terhadap distribusi aset bersih dan laba yang rendah kepada manajer dan pemegang saham sehingga kreditur cenderung meminta manajer untuk menyelenggarakan akuntansi yang konservatif. Hasil penelitian ini mendukung penelitian yang dilakukan oleh Fani Risdiyani dan Kusmuriyanto (2015) yang menyatakan bahwa leverage berpengaruh terhadap konservatisme akuntansi.

\section{Pengaruh Profitabilitas Terhadap Konservatisme Akuntansi}

Hasil dari pengujian variabel profitabilitas mendukung hipotesis ketiga yaitu terdapat pengaruh profitabilitas terhadap konservatisme akuntansi (Studi Empiris Pada Perusahaan Manufaktur yang Terdaftar di Bursa Efek Indonesia 2015-2019). Hasil ini ditunjukkan dengan koefisien regresi sebesar 2,083 yang berarti bahwa setiap kenaikan profitabilitas sebesar 1 satuan akan menaikkan konservatisme akuntansi sebesar 2,083 satuan. Berdasarkan hasil pengujian variabel profitabilitas menghasilkan nilai signifikansi sebesar 0,022 dan lebih kecil dari 0,05. Berdasarkan nilai signifikansi tersebut menunjukkan bahwa profitabilitas berpengaruh terhadap konservatisme akuntansi. Sehingga dapat dinyatakan bahwa profitabilitas berpengaruh positif dan signifikan terhadap konservatisme akuntansi (Studi Empiris Pada Perusahaan Manufaktur yang Terdaftar di Bursa Efek Indonesia 2015-2019).

Hasil penelitian ini mengindikasikan bahwa penerimaan hipotesis ini dikarenakan profitabilitas merupakan patokan dalam konservatisme akuntansi. Profitabilitas ialah rasio yang 
bertujuan untuk dapat mengetahui kemampuan perusahaan didalam menghasilkan laba selama periode tertentu serta memberikan gambaran mengenai tingkat efektifitas manajemen didalam melaksanakan kegiatan operasinya. Efektifitas manajemen dilihat dari laba yang dihasilkan terhadap penjualan serta investasi perusahaan dilakukan anggota organisasi untuk melaporkan dugaan dari pelanggaran yang dilakukan tersebut.

Hasil penelitian ini konsisten dengan hasil penelitian yang dilakukan oleh oleh Yuliani (2013) menerangkan bahwa profitability berpengaruh positif terhadap konservatisme akuntansi. Penelitian lain yang dilakukan oleh Choiriyah dan Almilia (2016) menunjukkan bahwa profitabilitas memiliki pengaruh yang signifikan terhadap konservatisme akuntansi, semakin tinggi tingkat profitabilitas suatu perusahaan, maka manajemen akan cenderung memilih akuntansi yang konservatif. Hal ini karena konservatisme digunakan oleh manajer untuk mengatur laba agar terlihat rata dan tidak terlalu memiliki fluktuasi.

Pengukuran rasio profitabilitas adalah dengan mengukur Return on equity atau ROE ialah suatu pengukuran dari penghasilan (income) yang tersedia bagi para pemilik perusahaan (baik itu pemegang saham biasa ataupun pemegang saham preferen atau khusus) atas modal yang mereka investasikan di dalam suatu perusahaan. Semakin tinggi tingkat profitabilitas, maka investor atau pemilik menilai bahwa kinerja perusahaan dalam memanfaatkan ekuitas untuk menghasilkan laba cukup baik, hal tersebut berarti manajer cukup baik dalam mengelolah perusahaan

\section{KESIMPULAN}

Berdasarkan hasil penelitian mengenai pengaruh financial distress, leverage dan profitabilitas terhadap konservatisme akuntansi dapat diambil kesimpulan sebagai berikut:

Variabel financial distress tidak berpengaruh signifikan terhadap Konservatisme Akuntansi (Studi Empiris Pada Perusahaan Manufaktur yang Terdaftar di Bursa Efek Indonesia 2015-2019). Variabel leverage berpengaruh signifikan terhadap Konservatisme Akuntansi (Studi Empiris Pada Perusahaan Manufaktur yang Terdaftar di Bursa Efek Indonesia 2015-2019). Variabel profitabilitas berpengaruh signifikan terhadap Konservatisme Akuntansi (Studi Empiris Pada Perusahaan Manufaktur yang Terdaftar di Bursa Efek Indonesia 2015-2019)

\section{SARAN}

Berdasarkan kesimpulan dan hasil serta pembahasan dari penelitian ini, berikut adalah saran yang bisa penulis sampaikan yakni sebagai berikut:

Berdasarkan hasil penelitian yang telah dilakukan, ada beberapa saran yang dapat menjadi pertimbangan untuk kedepannya. Penelitian selanjutnya sebaiknya menambah variabel-variabel independen lain seperti kepemilikan manajerial, kepemilikan institusional, kepemilikan publik, ukuran perusahaan yang mungkin berpengaruh lebih besar terhadap konservatisme akuntansi.

Penelitian selanjutnya dapat menggunakan dua alat ukur konservatisme akuntansi, agar mendapatkan hasil yang komprehensif dan lebih menggambarkan permasalahan dalam penelitian. Bagi pihak investor bisa menggunakan variabel tingkat hutang, ukuran perusahaan dan insentif pajak untuk melihat apakah perusahaan melakukan kebijakan akuntansi yang konservatif atau tidak, sebelum investor akan menanamkan modalnya di perusahaan tersebut. Hal ini karena konservatisme akuntansi, perusahaan cenderung melaporkan laba yang tidak sebenarnya, sehingga kesempatan investor untuk mendapatkan laba berupa dividen juga rendah. 


\section{DAFTAR PUSTAKA}

Alfian, a. (2013). Analisis faktor-faktor yang berpengaruh terhadap pemilihan konservatisme akuntansi (Studi pada Perusahaan Manufaktur yang Terdaftar di BEI Tahun 2009-2011). Skripsi. Fakultas Ekonomika Dan Bisnis Universitas Diponegoro.

Fauzan, A. W., \& Widodo, W. (2015). Analisis Pengaruh Investasi, Tenaga Kerja, dan Tingkat Pendidikan terhadap Pertumbuhan Ekonomi (Studi Kasus: Kabupaten/Kota di Provinsi Jawa Tengah tahun 2009-2013). Diponegoro Journal of Economics.

Brilianti, Dinny. 2013. "Faktor-Faktor Yang Mempengaruhi Penerapan Konservatisme Akuntansi Perusahaan. Accounting Analysis Journal.

Choiriyah, Nila. 2016. “ Pengaruh Profitabilitas, Likuiditas, Dan Tingkat Kesulitan Keuangan Perusahaan Terhadap Konservatisme Akuntansi”. STIE Perbanas Surabaya.

Dewi, Ni Kd Sri Lestari Dan Ketut Suryawan. 2014. "Pengaruh Struktur Kepemilikan Manajerial, Leverage, dan Financial Distress Terhadap Konservatisme Akuntansi. E-Jurnal Akuntansi Universitas Udayana.

Noviantari, N., \& Ratnadi, N. (2015). Pengaruh Financial Distress, Ukuran Perusahaan, Dan Leverage Pada Konservatisme Akuntansi. E-Jurnal Akuntansi.

Nugraha, R., \& Hapsari, D. W. (2015). Pengaruh Leverage, Profitabilitas, Ukuran Perusahaan terhadap Ketepatan Waktu Penyampaian Laporan Keuangan (Studi Empiris pada Perusahaan di Sektor Jasa yang Terdaftar di BEI periode 2010-2013). E-Proceeding of Management.

Setyaningsih, H. (2008). Pengaruh tingkat kesulitan keuangan perusahaan terhadap konservatisme. Jurnal Akuntansi Dan Investasi.

Saputri, Yuliani Diah. 2013. "Faktor-Faktor Yang Mempengaruhi Pilihan Perusahaan Terhadap Konservatisme Akuntansi”. Accounting Analysis Journal.

Watts, R. L. (2003). Conservatism in accounting part I: Explanations and implications. Accounting Horizons. https://doi.org/10.2308/acch.2003.17.3.207.

Zelmiynati, Riri. 2014. "Perkembangan Penerapan Prinsip Konservatisme Dalam Akuntansi. Jurnal Riset Dan Akuntansi Vol.05. 